\title{
SEASONAL ABUNDANCE OF MAJOR SUCKING AND CHEWING INSECTS OF GUAVA
}

\author{
Md. Ruhul Amin*, Shubhati Khisa, Habibur Rahman, Rayhanur Jannat ${ }^{1}$ \\ and Muhammad Badruzzaman ${ }^{2}$
}

Department of Entomology, Bangabandhu Sheikh Mujibur Rahman Agricultural University, Gazipur-1706, Bangladesh

\begin{abstract}
Seasonal abundances of the sucking insects, namely mealy bug, white fly and scale insects, and chewing insect viz., fruit fly was monitored during September, 2016 to June, 2017 in a guava Psidium guajava orchard. Sucking insect was monitored by weekly observation on the leaves and chewing insect was captured using methyl eugenol trap. The mealy bug, white fly and scale insects were abundant during 4th week of November to 4th week of January and they showed fluctuations in their population. The mealy bug, white fly and scale insects had peak abundance in the 1st week of January, 4th week of November and 1st week of December, respectively. The scale insect revealed significantly higher abundance compared to other sucking insects. Two species of fruit fly, namely Bactrocera tryoni and $B$. dorsalis were found in the guava orchard and $B$. tryoni showed significantly higher abundance compared to $B$. dorsalis both in winter and summer seasons. In winter, $B$. tryoni reached the peak abundance in the 2nd week of January and their peak abundance in summer occurred in the 1st week of May. The daily mean temperature and relative humidity influenced the abundance of the sucking and chewing insects. Temperature individually contributed 30.0, 59.6, 59.3\% abundance and temperature with relative humidity had $34.8,60.9$ and $73.5 \%$ abundance on mealy bug, white fly and scale insect, respectively. The effect of temperature on the abundance of fruit fly in winter and summer were 42.6 and $50.3 \%$, respectively and the combined effect of temperature with relative humidity were $68.7 \%$ in winter and $61.9 \%$ in summer.
\end{abstract}

Key words: Abundance, Bactrocera spp., Psidium guajava, temperature, humidity

\section{INTRODUCTION}

The climacteric fruit guava Psidium guajava L., originated in tropical America has been cultivated widely in many countries in the world. It is considered as the most important fruit of the family Myrtaceae and a major source of vitamin A, B and C, and also contains high amounts of calcium and pectin (Anita et al. 2012). Guava is an important fruit crop of Bangladesh that has been commercially cultivated in Gazipur, Barishal and Dinajpur districts. It claims to be the 5th most important fruits in area and production after banana, mango, pineapple and jackfruit (BBS 2018).

*Author for correspondence: <mramin.bsmrau@gmail.com>. ${ }^{1}$ Department of Plant Pathology, Bangabandhu Sheikh Mujibur Rahman Agricultural University, Gazipur, Bangladesh. ${ }^{2}$ Department of Biochemistry and Molecular Biology, Bangabandhu Sheikh Mujibur Rahman Agricultural University, Gazipur, Bangladesh.

(C) 2018 Zoological Society of Bangladesh DOI: https://doi.org/10.3329/bjz.v47i1.42025 
Insect infestation is the most important limiting factor of guava production in Bangladesh. This biotic factor deteriorates the yield and market value of the fruit. Various insect species cause damage to guava in different regions of the world and their abundance vary with geographic locations, availability of food sources and seasons of the year. Al-Fwaeer et al. (2013) identified aphids, medfly, mealy bugs, beetle, scale insect and thrips as the insect pests of guava in Jordan. Fruit flies are the most important insect pests cause enormous damage to guava and two species of fruit flies viz., Bactrocera dorsalis and Bactroceratryoni have been found predominant in guava orchards. Sarwar (2006) reported mealy bugs, stink bug, red-banded thrips, guava moth, guava whitefly and scale insect are major insect pests of guava in Pakistan. Baker et al. (2012) reported nine scale insect species are destructive to guava in Egypt.

Weather factors play role in multiplication, growth, development and distribution of insects and influence on their seasonal abundance (Dhaliwal and Arora 2001). Temperature is the most influential parameter of the meteorological factors affecting insect population dynamics (Arun 2003). Baker et al. (2012) reported that the abundance of the insect pest is related with weather factors and the lowest population density is during winter season.

Seasonal population dynamics of any insect pest provide knowledge on relationship between weather factors and insect abundance. It indicates the farmers of a particular area or region about management program of the pest. So, the growers can take proper control measures to prevent loss due to insect attack. Insect pest species of guava, their occurrence and sseasonal dynamics have been studied in many countries (Clarke et al. 2001, Sarada et al. 2001, Mwatawala et al. 2006). But there is scarcity of information on insect pest species of guava in Bangladesh, their nature of occurrence and seasonal abundance. So, the aim of the study is to know the abundance of the sucking (mealy bug, white fly and scale insect) and chewing (fruit fly) insects which cause significant infestation on guava, and to find out the effect of the meteorological factors such as temperature and relative humidity on the abundance of the insects.

\section{MATERIAL AND METHODS}

The study was conducted in the agroforestry field of Bangabandhu Sheikh Mujibur Rahman Agricultural University (BSMRAU), Gazipur, Bangladesh during September, 2016 to June, 2017. The study site is located in the middle of Bangladesh $\left(25^{\circ} 25^{\prime}\right.$ North latitude and $89^{\circ} 5^{\prime}$ East longitude). The site is surrounded by sal Shorea robusta Gaertn forest. The area of the agroforestry is $1000 \mathrm{~m}^{2}$ and constituted with mango (variety Amrapali), guava (variety IPSA 
peyara 3), lichi (variety bombai) and jack fruit trees and some ornamental plants.

Climatic conditions: The study area has a subtropical climate but seasonal, and characterized by a well-defined dry season (February to May), rainy season (June to September) and short winter (December and January). Annual mean maximum and minimum temperatures, relative humidity and rainfall are 36.0 and $12.7^{\circ} \mathrm{C}, 65.8 \%$ and $237.6 \mathrm{~cm}$, respectively.

Observation of the abundance of sucking insects: During the study the agroforestry area was free from any management practices of insect pest. Abundance of the sucking insects, namely white fly, mealy bug and scale insect was monitored by weekly observation of the plants. In each observation day, ten infested leaves for each of the sucking insects were selected randomly from different directions of the plant and the numbers of nymphs and adults of the insects per leaf was counted by using hand lens.

Installation of methyl eugenol trap and collection of fruit flies: Abundance of fruit fly in the orchard was monitored during winter (January to February) and summer (May to June) seasons of the year when the plants had developed fruits. To assess the seasonal changes of fruit fly abundance, sampling protocol was targeted on free-living male insects. Methyl Eugenol trap which was supplied by Ispahani Agro Limited was used to capture male insects. The trap was constructed with transparent plastic bottles of approximately one liter capacity. Two holes were cut, one in the lid and the other exactly the opposite to facilitate the entry of fruit flies. The holes were fitted with a PVC (Polymerizing vinyl chloride) pipe of about $1.5 \mathrm{~cm}$ diameters with a length of $8 \mathrm{~cm}$. The lure was suspended exactly in the center. Five traps were hung in the orchard weekly interval and each trap represented a replication. Two species of fruit fly, namely Bactrocera dorsalis and B. tryoni were found in the agroforestry area. The male flies of these species captured in each trap in a week were counted and the traps were substituted with new traps.

Collection of weather data: Mean daily temperature, relative humidity and rainfall data were collected from the weather station of BSMRAU.

Statistical analysis: One way analysis of variance (ANOVA) followed by Tukey posthoc statistic was employed for analyzing the mean abundance. Correlation coefficients were calculated for total abundance with meteorological parameters. All the analyses were performed using IBM SPSS 21.0 (IBM SPSS statistics 21, Georgia, USA). 


\section{RESULTS AND DISCUSSION}

Abundance of the sucking insects in the guava orchard along with the weather data during November, 2016 to January, 2017 is presented in Table 1. Mealy bug was abundant in the 4th week of November, 4th week of December, 1 st week of January and 4th week of January. The peak abundance (3.4/leaf) of this insect was found in the 1 st week of January when the temperature and relative humidity were $20.5^{\circ} \mathrm{C}$ and $58.0 \%$, respectively and there was no rainfall (Table 1). El-Serafi et al. (2004) reported that the guava mealy bug had three peaks per year in Egypt and the highest peak was found by late August (6.1/ leaf) and other two peaks were recorded by early January and the end of October. The present findings differed from these results because of the different climatic zone of the world.

Table 1. Distribution of weather parameters and major sucking insect population buildup on guava at different observation days during November, 2016 to January, 2017 in Gazipur, Bangladesh

\begin{tabular}{lccccccc}
\hline \multirow{2}{*}{$\begin{array}{c}\text { Observation } \\
\text { day }\end{array}$} & \multicolumn{3}{c}{ Weather parameters } & & \multicolumn{3}{c}{ Insect abundance (Number/leaf) } \\
\cline { 2 - 3 } \cline { 6 - 7 } & $\begin{array}{c}\text { Temperature } \\
\left({ }^{\circ} \mathrm{C}\right)\end{array}$ & $\begin{array}{c}\text { Relative } \\
\text { humidity } \\
(\%)\end{array}$ & $\begin{array}{c}\text { Rainfall } \\
(\mathrm{mm})\end{array}$ & & $\begin{array}{c}\text { Mealy bug } \\
\text { (Ferrisia } \\
\text { virgate) }\end{array}$ & $\begin{array}{c}\text { White fly } \\
\text { (Bemisia } \\
\text { tabaci) }\end{array}$ & $\begin{array}{c}\text { Scale insect } \\
\text { (Phyllotreta } \\
\text { vittula) }\end{array}$ \\
\hline 24 November & 26.0 & 63.0 & 0.0 & & 2.8 & 5.7 & 25.2 \\
01 December & 21.5 & 68.0 & 0.0 & & 0.0 & 4.9 & 28.5 \\
$07 \quad "$ & 22.0 & 66.0 & 0.0 & & 0.0 & 0.9 & 24.4 \\
$14 \quad "$ & 20.3 & 54.0 & 0.0 & & 0.0 & 2.8 & 6.0 \\
$21 \quad "$ & 19.8 & 53.0 & 0.0 & & 0.0 & 0.6 & 5.8 \\
$28 \quad "$ & 20.0 & 64.0 & 0.0 & & 0.1 & 1.9 & 6.8 \\
04 January & 20.5 & 58.0 & 0.0 & & 3.4 & 3.3 & 9.6 \\
11 & 18.0 & 54.0 & 0.0 & & 0.0 & 0.7 & 5.9 \\
18 " & 18.0 & 43.0 & 0.0 & & 0.0 & 0.6 & 5.2 \\
25 & 19.5 & 50.0 & 0.0 & & 0.2 & 0.8 & 3.0 \\
\hline
\end{tabular}

White fly was abundant during November, 2016 to January, 2017 and the fly reached the peak abundance (5.7/leaf) in the 4 th week of November and then declined and showed fluctuation (Table 1). At the time of the peak abundance, temperature and relative humidity were $26.0^{\circ} \mathrm{C}$ and $63.0 \%$, respectively, and there was no rainfall. El- Serafi et al. (2004) observed the peak abundance of white fly in mid-November, early January and February of the year 2001 in Egypt, and reported that the highest peak (4.6/leaf) was in the mid-November.

Scale insect showed increasing trend of their abundance from 4 th week of November and reached the peak (28.5/leaf) in the 1st week of December and then declined and had fluctuations (Table 1). At the time of the peak abundance 
temperature and relative humidity were $21.5^{\circ} \mathrm{C}$ and $68.0 \%$, respectively, and there was no rainfall. El-Serafi et al. (2004) observed two peaks of the abundance of scale insect (14.1/leaf) in Egypt in the year 2002 and the peaks were found by early August and late October. In the present study the scale insect showed their peak abundance in the first week of December. Fig. 1 showed that the mean abundance of the sucking insects varied from 0.7 to $12.1 /$ leaf and the results differed significantly $\left(\mathrm{F}_{2,27}=11.2, \mathrm{p} \leq 0.001\right)$. Scale insect revealed the highest and the other two insects showed statistically similar abundance.

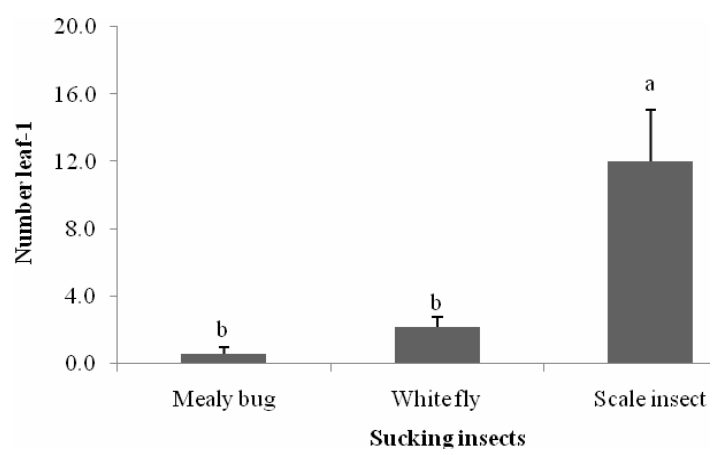

Fig. 1. Mean abundance of different sucking insects on guava leaf during November 2016 to January 2017 in Gazipur, Bangladesh.

The fruit flies showed fluctuation in their population on guava and $B$. tryoni revealed higher abundance compared to $B$. dorsalis both in winter and summer seasons (Table 2). In winter, B. dorsalis revealed three peaks $(2.9 /$ trap) in their abundance and the peaks were occurred in the 3rd and 5th week of January and 1st week of February. Abundance of $B$. tryoni reached to the peak (9.3/trap) in the 2nd week of January and then declined. In winter, there was no rainfall and temperature and relative humidity ranged from 16.3 to $23.0^{\circ} \mathrm{C}$ and 43.0 to $59.0 \%$, respectively. In summer, both the species had peak abundance $(B$. dorsalis and $B$. tryoni were 5.7 and 7.9/trap, respectively) in the $1^{\text {st }}$ week of May and then declined. At that time temperature and relative humidity were $27.0^{\circ} \mathrm{C}$ and $81.0 \%$, respectively and there was no rainfall.

The mean abundance of the fruit flies in the guava orchard during winter and summer seasons ranged from $1.7 \pm 0.4$ to $5.9 \pm 0.7 /$ trap (Fig. 2) and the results differed significantly $\left(\mathrm{F}_{3,28}=10.2, \mathrm{p}<0.001\right)$. B. tryoni showed statistically similar abundance both in winter and summer but significantly higher compared to $B$. dorsalis. 
Table 2. Distribution of weather parameters and major chewing insect population buildup on guava at different observation days during winter and summer 2017 in Gazipur, Bangladesh

\begin{tabular}{|c|c|c|c|c|c|c|}
\hline \multirow[t]{2}{*}{ Season } & \multirow{2}{*}{$\begin{array}{c}\text { Observation } \\
\text { day }\end{array}$} & \multicolumn{3}{|c|}{$\begin{array}{c}\text { Weather } \\
\text { parameters }\end{array}$} & \multicolumn{2}{|c|}{$\begin{array}{l}\text { Insect abundance } \\
\text { (Number/trap) }\end{array}$} \\
\hline & & $\begin{array}{l}\text { Temp. } \\
\left({ }^{\circ} \mathrm{C}\right)\end{array}$ & $\begin{array}{c}\text { Relative } \\
\text { humidity (\%) }\end{array}$ & $\begin{array}{l}\text { Rainfall } \\
\text { (mm) }\end{array}$ & $\begin{array}{c}\text { Bactrocera } \\
\text { dorsalis }\end{array}$ & $\begin{array}{c}\text { Bactrocera } \\
\text { tryoni }\end{array}$ \\
\hline \multirow[t]{8}{*}{ Winter } & 08 January & 18.0 & 47.0 & 0.0 & 1.4 & 9.3 \\
\hline & $15 "$ & 16.3 & 43.0 & 0.0 & 2.9 & 7.1 \\
\hline & $22 "$ & 20.5 & 48.0 & 0.0 & 2.4 & 6.4 \\
\hline & $29 \quad "$ & 20.5 & 52.0 & 0.0 & 2.9 & 6.7 \\
\hline & 05 February & 22.0 & 46.0 & 0.0 & 2.9 & 5.9 \\
\hline & $12 "$ & 21.5 & 51.0 & 0.0 & 0.5 & 5.0 \\
\hline & $19 "$ & 23.0 & 52.0 & 0.0 & 0.3 & 3.6 \\
\hline & $26 "$ & 20.8 & 59.0 & 0.0 & 0.3 & 3.0 \\
\hline \multirow[t]{8}{*}{ Summer } & 03 May & 27.0 & 81.0 & 0.0 & 5.7 & 7.9 \\
\hline & $10 "$ & 28.0 & 83.0 & 0.0 & 5.6 & 7.1 \\
\hline & $17 "$ & 30.0 & 89.0 & 0.0 & 5 & 6.1 \\
\hline & $24 "$ & 29.0 & 87.0 & 0.0 & 4.7 & 5.7 \\
\hline & $31 "$ & 32.0 & 80.0 & 0.0 & 4.3 & 5.0 \\
\hline & 07 June & 33.0 & 81.0 & 0.0 & 2.9 & 4.7 \\
\hline & $14 "$ & 29.0 & 84.0 & 0.0 & 1.4 & 4.3 \\
\hline & $21 "$ & 28.0 & 80.0 & 0.0 & 0.4 & 3.6 \\
\hline
\end{tabular}

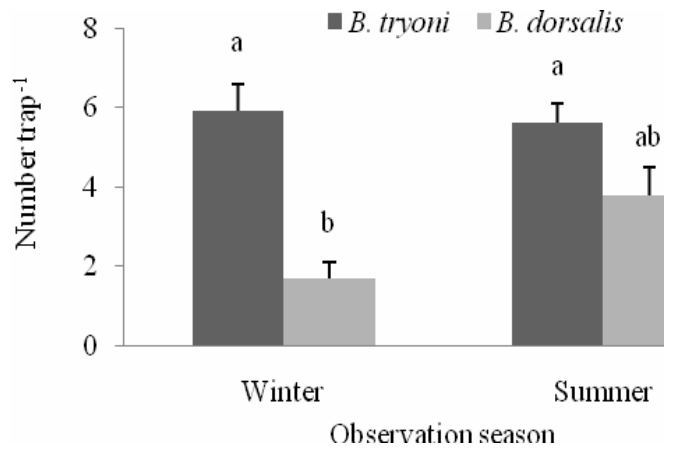

Fig. 2. Mean abundance of fruit fly species (Bactrocera tryoni and B. dorsalis) in guava orchard during winter and summer, 2017.

The variations of the meteorological conditions, blooming flowers and availability of the tender fruits during the study affect the population dynamics of the pest. Vargas et al. (2013) reported that the guava fruit fly showed most abundance in Hawaii during March to April and September to November, which coincided with the guava fruiting season. Liu and Ye (2005) found that the population of the fly was closely related to the fruiting period of host plants. 
The daily mean temperature and relative humidity had insignificant positive correlation with mealy bug and the results showed that the temperature individually exerted $30.0 \%$ population abundance and temperature with combination of relative humidity had $34.8 \%$ abundance, which was statistically insignificant (Table 3).

Table 3. Multiple regression models along with coefficients of determination $\left(R^{2}\right)$ regarding the impact of weather parameters on the seasonal abundance of the major insect pests of guava

\begin{tabular}{|c|c|c|c|c|c|c|}
\hline \multirow{2}{*}{$\begin{array}{l}\text { Insect } \\
\text { Mealy bug } \\
\text { (Ferrisia } \\
\text { virgata) }\end{array}$} & \multirow{2}{*}{$\begin{array}{c}\begin{array}{c}\text { Regression } \\
\text { equation }\end{array} \\
\mathrm{Y}=-5.706+0.309 \mathrm{X}_{1}\end{array}$} & \multirow{2}{*}{$\begin{array}{c}\mathrm{R}^{2} \\
0.300\end{array}$} & \multirow{2}{*}{$\begin{array}{c}100 \\
\mathrm{R}^{2} \\
30.0\end{array}$} & \multirow{2}{*}{$\begin{array}{c}\begin{array}{c}\text { Role of } \\
\text { individual } \\
\text { factor }\end{array} \\
30.0\end{array}$} & \multicolumn{2}{|c|}{$\begin{array}{c}\mathrm{F} \\
\text { statistic }\end{array}$} \\
\hline & & & & & $\mathrm{F}_{1,8}=3.4$ & $\mathrm{p}=0.10$ \\
\hline & $\begin{array}{l}Y=-5.171+0.415 X_{1}- \\
0.047 X_{2}\end{array}$ & 0.348 & 34.8 & 4.8 & $\mathrm{~F}_{2,7}=1.9$ & $\mathrm{p}=0.22$ \\
\hline \multirow{2}{*}{$\begin{array}{l}\text { White fly } \\
\text { (Bemisia } \\
\text { tabaci) }\end{array}$} & $Y=-10.823+0.634 X_{1}$ & 0.596 & 59.6 & 59.6 & $\mathrm{~F}_{1,8}=11.8$ & $\mathrm{p}<0.01$ \\
\hline & $\begin{array}{l}Y=-11.223+0.556 \mathrm{X}_{1}+ \\
0.035 \mathrm{X}_{2}\end{array}$ & 0.609 & 60.9 & 1.3 & $\mathrm{~F}_{2,7}=5.5$ & $\mathrm{p}<0.05$ \\
\hline \multirow{2}{*}{$\begin{array}{l}\text { Scale insect } \\
\text { (Phyllotreta } \\
\text { vittula) }\end{array}$} & $Y=-55.597+3.290 X_{1}$ & 0.593 & 59.3 & 59.3 & $\mathrm{~F}_{1,8}=11.7$ & $\mathrm{p}<0.01$ \\
\hline & $\begin{array}{l}Y=-62.579+1.914 X_{1}+ \\
0.615 X_{2}\end{array}$ & 0.735 & 73.5 & 14.2 & $\mathrm{~F}_{2,7}=9.7$ & $\mathrm{p}<0.05$ \\
\hline \multirow{2}{*}{$\begin{array}{l}\text { Fruit fly } \\
\text { (Winter) } \\
\text { (Bactrocera } \\
\text { dorsalis) }\end{array}$} & $\mathrm{Y}=25.281-0.872 \mathrm{X}_{1}$ & 0.426 & 42.6 & 42.6 & $\mathrm{~F}_{1,6}=4.5$ & $p=0.08$ \\
\hline & $\begin{array}{l}Y=34.474-0.450 X_{1}+ \\
0.357 X_{2}\end{array}$ & 0.687 & 68.7 & 26.1 & $\mathrm{~F}_{2,5}=5.5$ & $p=0.06$ \\
\hline \multirow{2}{*}{$\begin{array}{l}\text { Fruit fly } \\
\text { (Summer) } \\
\text { (Bactrocera } \\
\text { tryoni) }\end{array}$} & $\mathrm{Y}=34.438-1.261 \mathrm{X}_{1}$ & 0.503 & 50.3 & 50.3 & $\mathrm{~F}_{1,6}=6.1$ & $\mathrm{p}<0.05$ \\
\hline & $\begin{array}{l}Y=1.902-1.264 \mathrm{X}_{1}+ \\
0.392 \mathrm{X}_{2}\end{array}$ & 0.619 & 61.9 & 11.6 & $\mathrm{~F}_{2,5}=4.1$ & $p=0.09$ \\
\hline
\end{tabular}

$\mathrm{Y}$, insect population; $\mathrm{X}_{1}$, temperature $\left({ }^{\circ} \mathrm{C}\right) ; \mathrm{X}_{2}$, relative humidity $(\%)$.

Abundance of white fly revealed significant positive correlation with daily mean temperature and relative humidity, and the results exerted that the temperature individually contributed $59.6 \%$ abundance and temperature with combination of relative humidity was $60.9 \%$, which was statistically significant (Table 2). 
Abundance of scale insect was positively correlated with daily mean temperature and relative humidity, and the results showed that the temperature individually exerted $59.3 \%$ abundance and temperature with combination of relative humidity was $73.5 \%$, which was statistically significant (Table 2 ).

Fruit fly showed insignificant negative correlation with daily mean temperature and relative humidity in winter, and the results exerted that the temperature individually contributed $42.6 \%$ abundance and temperature with combination of relative humidity was $68.7 \%$, which was statistically insignificant (Table 3). In summer, fruit fly showed significant negative correlation with daily mean temperature and insignificant positive correlation with relative humidity, and the results exerted that the temperature individually contributed $50.3 \%$ abundance and temperature with combination of relative humidity was $61.9 \%$, which was statistically insignificant (Table 3).

The present findings showed agreement with Rajitha and Viraktamath (2006) who reported that the $B$. dorsalis showed a highly significant and positive correlation with minimum temperature and relative humidity. The role of abiotic factors is closely related with fly distribution (Vera et al. 2002, Duyck et al. 2006). Jalaluddin et al. (2001) recorded positive correlation of minimum temperature and relative humidity with the population of guava fruit fly, B. tryoni. Rainfall appeared as the most important factor for fruit fly population fluctuation and infestation (Chen et al. 2006). But there was no rainfall during the present study.

Bangladesh is a subtropical country and the air temperature remains quite high in summer but not very cold in winter. However, stepwise regression analysis indicated that temperature and relative humidity showed relation with the insect population of guava. Fluctuation of the fruit fly population is due to prevalence of fruiting and flowering time of the guava.

The findings indicated that the sucking insects showed higher abundance during November to January and abundance of fruit flies were related with fruiting season, when the growers should be more conscious for implementation of integrated management program.

\section{LITERATURE CITED}

AL FWAEER, M., ABO-ABIED, I., ABO-ALLOSH, A., HALYBIH, M., OBEIDAT, K., ATAWEE, E and ALHAWAMLEH, H. 2013. Study of pests attacking guava in Jordan. Angewandten Biol. Fors. 1: 43-48.

ANITA, M., SIVARAM, V. and JAYARAMAPPA, K.V. 2012. Influence of bee attractants on pollination and yield parameters in guava (Psidium guajavaL.). Intl. J. Plant Reprod. Biol. 4: 41-46.

ARUN, P.R. 2003. Butterflies of Siruvani forests of Western Ghats, with notes on their seasonality. Zool. Print J. 18:1003-1006. 
BAKER, R.F.A., MOUSA, S.F., HAMOUDA, L.S., BADAWY, R.M. and ATTIA, S.A. 2012. Scale insects infesting guava trees and control measure of Pulvinaria psidii (Hemiptera: Coccidae) by using the alternative insecticides. Egypt. Acad. J. Biol. Sci. 5: 89-106.

BANGLADESH BUREAU OF STATISTICS (BBS). 2018. Year Book of Agricultural Statistics 2017. Statistics and Informatics Division (SID), Ministry of Planning. Government of the People's Republic of Bangladesh.

CHEN, P., YE, H. and LIU, J. 2006. Population dynamics of Bactrocera dorsalis (Diptera: Tephritidae) and analysis of the factors influencing the population in Ruili, Yunnan Province, China. Acta. Ecol. Sinica. 26: 2801-2808.

ClARKE, A.R., ALlWOOD, A., CHINAJARIYAWONG, A., DREW, R.A.I., HENGSAWAD, M., JIRASURAT, C., KONG, S., KRITSANEEPAIBOON, S. and VIJAYSEGARAN, S. 2001. Seasonal abundance and host use patterns of seven Bactrocera Macquart species (Diptera: Tephritidae) in Thailand and Peninsular Malaysia. Raffles Bull. Zool. 49: 207-220.

DHALIWAL, G.S. and ARORA, R. 2001. Integrated Pest Management Concepts and Approaches. Kalyani Pulishers, New Delhi, India. 27-60.

DUYCK, P.F., DAVID, P. and QUILICI, S. 2006. Climatic niche partitioning following successive invasions by fruit flies in La Reunion. J. Anim. Ecol. 75: 518-526.

EL SERAFI, H.A., GHANIM, A.A., EL- HENEIDY, A.H. and EL- SHERBENIE, M.K. 2004. Ecological studies on certain insects infesting guava orchards and their predatory insects at Mansoura district. Egyptian J. Biol. Pest Cont. 14: 77-85.

JALALUDDIN, S.M., NATARAJAN, K. and KATHULLA, S.S. 2001. Population fluctuation of the guava fruit fly, Bactrocera correcta (Bezzi) in relation to host and abiotic factors. J. Exp. Zool. 4: 323-327.

LIU, J.H. and YE. 2005. Population dynamics of Bactrocera dorsalis (Diptera: Tephritidae) in Yuanjiang dry-hot valley, Yunnan with an analysis of the related factors. Acta Entomol. Sinica. 48: 706-711.

MWATAWALA, M.W., MEYER, D., MAKUNDI, R. and MAERERE, A. 2006. Seasonality and host utilization of the invasive fruit fly, Bactrocera invadens (Diptera: Tephritidae) in central Tanzania. J. Appl. Entomol. 130: 530-537.

RAJITHA, A.R. and VIRAKTAMATH, S. 2006. Monitoring of fruit flies (Diptera: Tephritidae) in guava orchard at Dharwad, Karnataka. Karnataka J. Agric. Sci. 19: 45-49.

SARADA, G., MAHESWARI, T. and PURUSHOTHAM, K. 2001. Seasonal incidence and population fluctuation of fruit flies in mango and guava. Indian J. Entomol. 63: 272-276.

SARWAR, M. 2006. Occurrence of insect pests on guava (Psidium guajava) tree. Pak J Zool. 38: 197200.

VARGAS, R.I., STARK, J.D., BANKS, J., LEBLANC, L., MANOUKIS, N.C. and PECK, S. 2013. Spatial dynamics of two oriental fruit fly (Diptera: Tephritidae) parasitoids, Fopiusaris anus and Diachasmimorpha longicaudata (Hymenoptera: Braconidae), in a guava orchard in Hawaii. Environ. Entomol. 42: 888-901.

VERA, M.T., RODRIGUEZ, R., SEGURA, D.F., CLADERA, J.L. and SUTHERST, R.W. 2002. Potential geographical distribution of the Mediterranean fruit fly, Ceratitis capitate (Diptera: Tephritidae), with emphasis on Argentina and Australia. Environ. Entomol. 31: 1009-1022. 